\title{
KEUSANGAN LITERATUR, PARO HIDUP, DAN ZIPF PADA ARTIKEL BIDANG PERTANIAN
}

\author{
Nabila Ainun Nazifah \\ Program Studi Ilmu Perpustakaan \\ Fakultas Adab dan Humaniora \\ UIN Raden Fatah Palembang \\ Email: nabilanazifah1998@gmail.com
}

\begin{abstract}
Abstrak
Bibliometrik merupakan kajian terhadap dokumen atau karya ilmiah dengan menerapkan metode matematika dan statistika, ruang lingkup dalam kajian bibliometrik ini adalah tentang produktivitas pengarang, keusangan literatur, paro hidup literatur, dan core jurnal/artikel. Semua kajian itu dapat dianalisis menggunakan rumus bradford, Zipf, dan lotka. Didalam artikel ini dideskripsikan mengenai keusangan literatur bidang pertanian dan usia paro hidup artikel bidang pertanian tahun 2006-2012, serta penghitungan frekuensi kata menggunakan rumus zipf ditahun 2008-2012. Untuk mengetahui informasi terkait hal tersebut maka penulis menggunakan metode penelitian kuantitatif dengan pendekatan deskriptif, yang dimana melakukan penekanan pada data-data numerical atau angka yang diolah dengan menggunakan metode statistik. Serta kesimpulan dari artikel ini adalah untuk keusangan literatur bidang pertanian periode tahun 2006-2012 penghitungan median tahun sitasinya berjumlah lebih dari 14 tahun, maka dapat diperkirakan bahwa literatur tersebut telah usang.

Sedangkan untuk paro hidupnya, literatur bidang pertanian dari 10 artikel terletak di pengarang Sunarti tahun 2010 yang mempunyai referensi tahun 2000-2007. Jadi, 2018-2010 yaitu 8 tahun. Dengan begitu maka dapat didapat bahwa paro hidup literatur bidang pertanian 8 tahun. Serta untuk analisa zipf didapatkan kesimpulan bahwa selama periode tahun 2008-2012 dalam 5 artikel terlihat bahwa subjek yang paling dominan dilakukan penelitian adalah subjek tentang Tanaman ladang, pertanian, dan perkebunan, dengan presentase total $40 \%$, Serta terdapat juga beberapa penelitian yang dilakukan pada subjek Teknik tertentu: alat, perlengkapan, materi, Pengolahan hasil ternak dan produk budidaya serangga, serta Berburu, penangkapan ikan, konservasi, teknologi. Pada subjek-subjek tersebut terlihat $20 \%$ penelitiannya. Sedangkan untuk subjek yang lainnya masih belum ada dilakukannya penelitian penulisan karya ilmiah berupa artikel.
\end{abstract}

Kata Kunci: Literatur, Bibliometrik, Keusangan 


\begin{abstract}
Bibliometrics is a study of documents or scientific works by applying mathematical and statistical methods, the scope of this bibliometric study is about the productivity of the author, obsolescence of literature, half-life of literature, and core journals / articles. All studies can be analyzed using the bradford formula, Zipf, and lotka. This article describes the obsolescence of agricultural literature and the age of the half-life of agricultural articles in 2006-2012, as well as the calculation of word frequency using the zipf formula in 20082012. To find out information related to this, the authors use quantitative research methods with a descriptive approach, which emphasizes numerical data or numbers that are processed using statistical methods. As well as the conclusion of this article is for the obsolescence of agricultural literature in the period 2006-2012 the calculation of the median year sitas totaled more than 14 years, it can be estimated that the literature is obsolete.

As for his half-life, the agricultural literature from 10 articles is located in the author of Sunarti in 2010 which has references in 2000-2007. So, 2018-2010 is 8 years. That way it can be found that the half-life of agricultural literature is 8 years. And for the zipf analysis it was concluded that during the period of 2008-2012 in 5 articles it was seen that the most dominant subject of research was the subject of Field crops, agriculture, and plantations, with a total percentage of 40\%, and there were also several studies conducted on the subject Specific techniques: tools, equipment, materials, processing of livestock products and insect cultivation products, as well as hunting, fishing, conservation, technology. On these subjects $20 \%$ of his research was seen. As for other subjects, there is still no research on writing scientific papers in the form of articles.
\end{abstract}

Keywords: Literature, Bibliometrics, Obsolescence 


\section{PENDAHULUAN}

\section{A. LATAR BELAKANG}

Bibliometika berasal dari kata biblio yang berarti buku dan metrika yang berarti pengukuran. ${ }^{1}$ Bibliometrika dapat dikatakan sebagai kegiatan mengukur buku atau literatur dengan menggunakan pendekatan matematika dan statistika. Bibliometrik juga sebagai ilmu yang menerapkan penelitiannya pada bibliografi bukan hanya sebatas penelitian terhadap daftar rujukan, akan tetapi bibliografi

tersebut dapat dijadikan cermin untuk melihat perkembangan suatu disiplin ilmu.

Bibliometrika adalah suatu evaluasi kuantitatif dari pola publikasi dari semua komunikasi mikro dan makro bersama dengan kepengarangannya dengan menggunakan perhitungan matematika dan statistik, serta Bibliometrika adalah suatu evaluasi kuantitatif dari pola publikasi dari semua bentuk komunikasi baik mikro maupun makro bersama dengan kepengarangannya dengan menggunakan perhitungan matematika dan statistika. $^{2}$

Bibliometrika dalam analisisnya, menganalisis sitiran yang dimana dapat mengataui produktivitas pengarang, Core Literatur, keusangan literatur, dan paro hidup literatur. Dalam melakukan semua itu diperlukannya rumus, atau dalil hukum sesuai dengan kajiannya,

${ }^{1}$ Line and Sandison, dalam sulistyo basuki, Pengantar Ilmu Informasi: Buku Pedoman, (Jakarta: Pusat antar Universitas Ilmu Komputer Universitas Indonesia, 1988), hlm. 90

${ }^{2}$ Sulistyo Basuki, Pengantar dokumentasi, (Bandung: Rekayasa Sains, 2004), hlm. 79 
misalnya menggunakan hukum lotka, zipf, breadford. Yang dimana hasil dari analisis ini adalah dapat memberikan manfaat terbaik untuk perpustakaan, salah satunya adalah untuk memudahkan dalam melihat perkembangan sebuah literatur, dan dapat melakukan wedding / penyiangan terhadap koleksi-koleksi yang tidak digunakan lagi sehingga dapat memanfaatkan rakrak buku secara efektivitas.

Berdasarkan teori diatas, terlihat bahwa keusangan literatur timbul karena semakin banyaknya karya ilmiah yang informasinya lebih muktahir. Serta dengan begitu maka akan semakin banyak informasi yang diakses sehingga cukup sulit untuk mengetahui subjek-subjek penelitian apa saja yang masih sedikit di teliti, dan dengan analisis ini dapat diketahui seberapa muktahir informasi yang dibuat oleh peneliti didalam suatu disiplin ilmu. Oleh karena itu penulis tertarik untuk menganalisa keusangan literatur, paro hidup literatur, dan frekuensi kata pada artikel, khususnya artikel dibidang Pertanian.

\section{B. RUMUSAN MASALAH}

a. Bagaimana Tingkat Keusangan Literatur Pada Artikel Bidang Pertanian di Tahun 2006-2012?

b. Bagaimana Paro Hidup Usia dan Keusangan Literatur Pada Artikel Bidang Pertanian di Tahun 2006-2012?

c. Bagaimana Penerapan Dalil Zipf Pada Artikel Bidang Pertanian di Tahun 2008-2012?

\section{METODELOGI PENELITIAN}

Penelitian ini menggunakan metode penelitian kuantitatif dengan pendekatan deskriptif, yang dimana 
melakukan penekanan pada data-data numerical atau angka yang diolah dengan menggunakan metode statistik.

\section{TUJUAN PEMBAHASAN}

a. Untuk mengetahui keusangan literatur dan usia paro hidup pada artikel bidang pertanian di tahun 20062012.

b. Untuk mengetahui subjek-subjek yang sering dilakukan penelitian pada bidang pertanian, dengan menggunakan analisis dalil zipf.

\section{PEMBAHASAN}

\section{A. KEUSANGAN LITERATUR}

Keusangan literatur / Obsolescence berasal dari kata obsolete berarti out-of-date, no longer in use, no longer valid atau no longer fashionable. ${ }^{3}$ Keusangan literatur merupakan keadaan dimana penggunaan suatu dokumen sebagai sumber informasi berkurang nilainya atau bahkan hilang dikarenakan jarang atau sudah tidak lagi digunakan oleh pengguna karena munculnya literatur

yang lebih baru. Keusangan literatur (Obsolescence) terdapat pada informasi yang ada di dalam dokumen. Hal Ini terjadi disebabkan oleh perkembangan ilmu pengetahuan yang terjadi setiap hari dan tidak dapat dihindari. Kajian mengenai keusangan literatur ini

${ }^{3}$ Sitti husaebah pattah, "pemanfaatan kajian bibliometrika sebagai metode evaluasi dan kajian dalam ilmu perpustakaan dan informasi”, Khazanah Al-Hiqmah, Vol.1, No.1, (Juni 2013), hlm. 37 
menjelaskan tentang penggunaan dokumen atau literatur yang berhubungan dengan usia dari literatur tersebut.

Hasil dari analisis keusangan literatur memiliki manfaat bagi perpustakaan, dimana dalam hal ini adalah dapat digunakan sebagai penyiangan (weeding) koleksi yang tidak digunakan lagi, dapat memanfaatkan rak/tempat yang terbatas,pemisahan koleksi yang digunakan dengan frekuensi tinggi dan rendah, serta bermanfaat untuk mengefektivitaskan sebuah layanan.

Dengan begitu maka hasil dari analisis literatur sangat bermanfaat sekali bagi perpustakaan, berikut adalah contoh analisis keusangan literatur bidang pertanian:

TABEL KEUSANGAN LITERATUR BIDANG PERTANIAN

\begin{tabular}{|c|c|c|c|c|c|c|}
\hline No. & Judul Artikel & $\begin{array}{c}\text { Pengarang/ } \\
\text { Tahun }\end{array}$ & Tahun & $\begin{array}{l}\text { Jumlah } \\
\text { dokumen }\end{array}$ & Median & Keusangan \\
\hline \multirow{9}{*}{1.} & \multirow{9}{*}{$\begin{array}{c}\text { Pola Pertanian } \\
\text { Terpadu } \\
\text { Ternak Dan } \\
\text { Tanaman } \\
\text { Hortikultura } \\
\text { Di Kota Pekan } \\
\text { Baru / Jurnal } \\
\text { Perternakan } \\
\text { Vol } 9 \text { No } 2 \\
\text { September } \\
2012 \\
\end{array}$} & \multirow{9}{*}{ L. Siswati/2012 } & 2011 & 1 & \multirow{9}{*}{$9 / 2=4,5$} & \multirow{9}{*}{$\begin{array}{c}2012- \\
2005=7 \\
\text { Tahun }\end{array}$} \\
\hline & & & 2009 & 1 & & \\
\hline & & & 2008 & 1 & & \\
\hline & & & 2007 & 1 & & \\
\hline & & & 2005 & 1 & & \\
\hline & & & 2003 & 1 & & \\
\hline & & & 2002 & 1 & & \\
\hline & & & 2001 & 1 & & \\
\hline & & & 1991 & 1 & & \\
\hline \multirow{7}{*}{2.} & \multirow{7}{*}{$\begin{array}{c}\text { Identifikasi } \\
\text { Faktor-Faktor } \\
\text { Sosial- } \\
\text { Ekonomi } \\
\text { Migrasi Tenaga } \\
\text { Kerja (Kasus } \\
\text { Ibu Rumah } \\
\text { Tangga Yang } \\
\text { Bekerja Dari }\end{array}$} & \multirow{7}{*}{$\begin{array}{c}\text { Agus } \\
\text { Sumanto/2009 }\end{array}$} & 2004 & 1 & \multirow{7}{*}{$13 / 2=6,5$} & \multirow{7}{*}{$\begin{array}{c}2009- \\
2003=6 \\
\text { Tahun }\end{array}$} \\
\hline & & & 2003 & 6 & & \\
\hline & & & 2002 & 1 & & \\
\hline & & & 2000 & 2 & & \\
\hline & & & 1999 & 1 & & \\
\hline & & & 1995 & 1 & & \\
\hline & & & 1991 & 1 & & \\
\hline
\end{tabular}




\begin{tabular}{|c|c|c|c|c|c|c|}
\hline & $\begin{array}{c}\text { Sektor } \\
\text { Pertanian Ke } \\
\text { Sektor Non } \\
\text { Pertanian)/ } \\
\text { Jurnal JESP } \\
\text { Vol } 1 \text { No 2, } \\
2009\end{array}$ & & & & & \\
\hline \multirow{15}{*}{3.} & \multirow{15}{*}{$\begin{array}{c}\text { Analisis } \\
\text { Referensi } \\
\text { Teknis Usaha } \\
\text { Tani Padi } \\
\text { Sawah } \\
\text { Aplikasi } \\
\text { Pertanian } \\
\text { Organik (Studi } \\
\text { Kasus Didesa } \\
\text { Sumber } \\
\text { Ngepoh, } \\
\text { Kecamatan } \\
\text { Lawang } \\
\text { Kabupaten } \\
\text { Malangmt } \\
\text { 2009-2010) / } \\
\text { Jurnal El } \\
\text { Hayah Vol 1 } \\
\text { No 4 Maret } \\
\text { 2011 }\end{array}$} & \multirow{15}{*}{ Tien/2011 } & 2009 & 1 & \multirow{15}{*}{$24 / 2=12$} & \multirow{15}{*}{$\begin{array}{c}2011- \\
2003=8 \\
\text { Tahun. }\end{array}$} \\
\hline & & & 2005 & 2 & & \\
\hline & & & 2004 & 6 & & \\
\hline & & & 2003 & 3 & & \\
\hline & & & 2000 & 2 & & \\
\hline & & & 1998 & 2 & & \\
\hline & & & 1997 & 1 & & \\
\hline & & & 1994 & 1 & & \\
\hline & & & 1989 & 1 & & \\
\hline & & & 1988 & 1 & & \\
\hline & & & 1986 & 1 & & \\
\hline & & & 1985 & 2 & & \\
\hline & & & \multirow{3}{*}{1977} & \multirow{3}{*}{1} & & \\
\hline & & & & & & \\
\hline & & & & & & \\
\hline \multirow{10}{*}{4.} & \multirow{10}{*}{$\begin{array}{c}\text { Strategi } \\
\text { Pengembangan } \\
\text { Sektor } \\
\text { Pertanian } \\
\text { Pasca Gempa } \\
\text { Bumi } \\
\text { Kabupaten } \\
\text { Bantul / } \\
\text { Jurnal } \\
\text { Ekonomi dan } \\
\text { Studi } \\
\text { Pembangunan } \\
\text { Vol } 9 \text { No 1 } \\
\text { April 2008 } \\
\end{array}$} & \multirow{10}{*}{$\begin{array}{c}\text { Agus Tri } \\
\text { Basuki/2008 }\end{array}$} & 2005 & 1 & \multirow{10}{*}{$10 / 2=5$} & \multirow{10}{*}{$\begin{array}{c}2008- \\
1994=14 \\
\text { tahun }\end{array}$} \\
\hline & & & 2000 & 1 & & \\
\hline & & & 1999 & 2 & & \\
\hline & & & 1994 & 1 & & \\
\hline & & & 1993 & 1 & & \\
\hline & & & 1991 & 1 & & \\
\hline & & & 1990 & 1 & & \\
\hline & & & 1989 & 1 & & \\
\hline & & & \multirow[b]{2}{*}{1988} & \multirow[b]{2}{*}{1} & & \\
\hline & & & & & & \\
\hline \multirow{5}{*}{5.} & \multirow{5}{*}{$\begin{array}{c}\text { Karakteristik } \\
\text { Pembakaran } \\
\text { Biobriket Dari } \\
\text { Campuran } \\
\text { Batu Bara Dan }\end{array}$} & \multirow{5}{*}{ Wahyudi / 2007} & 2001 & 1 & \multirow{5}{*}{$19 / 2=9,5$} & \multirow{5}{*}{$\begin{array}{c}2007- \\
1997=10 \\
\text { tahun }\end{array}$} \\
\hline & & & 2000 & 2 & & \\
\hline & & & 1999 & 5 & & \\
\hline & & & 1998 & 1 & & \\
\hline & & & 1997 & 1 & & \\
\hline
\end{tabular}




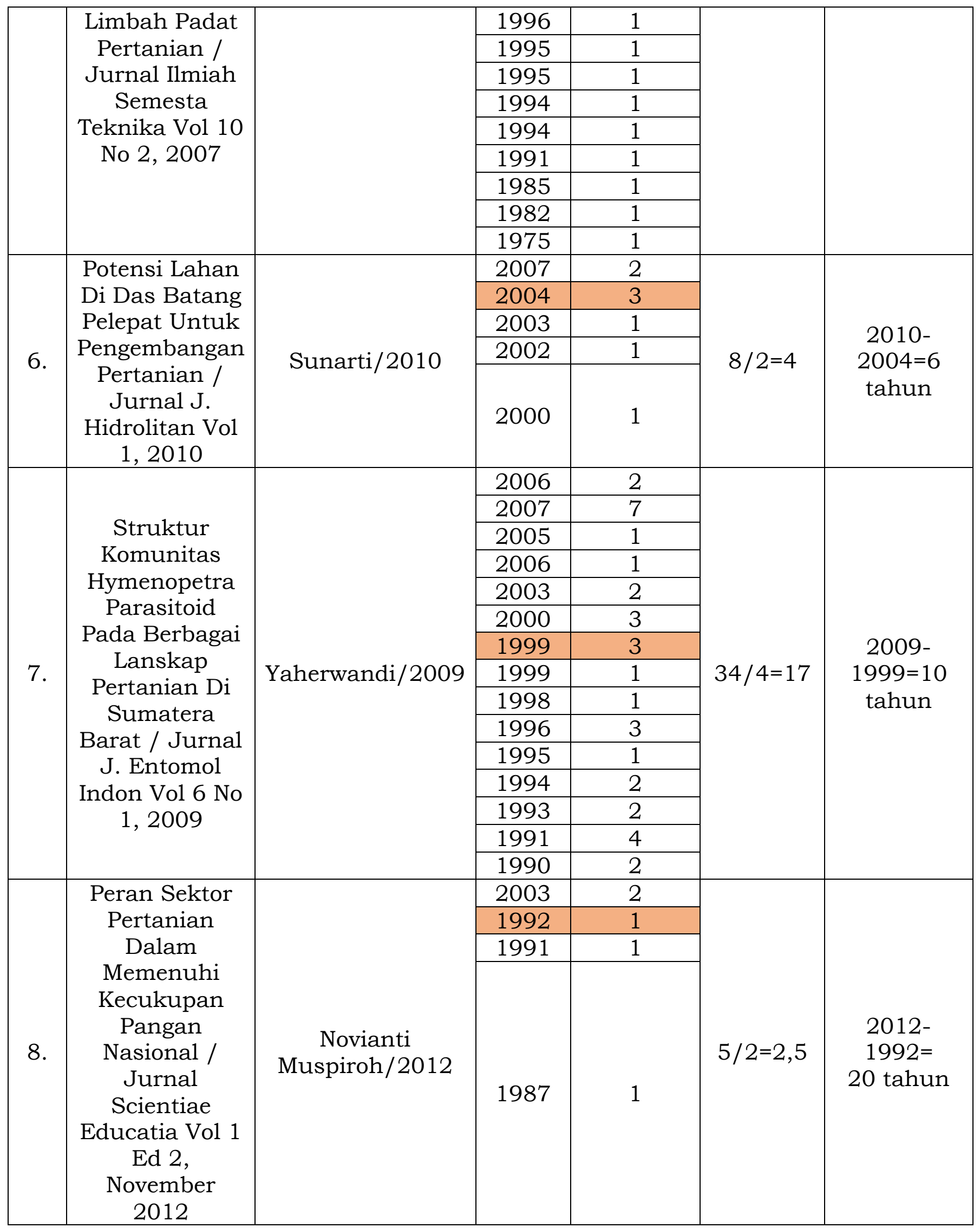




\begin{tabular}{|c|c|c|c|c|c|c|}
\hline \multirow{10}{*}{9.} & \multirow{10}{*}{$\begin{array}{c}\text { Penyebaran } \\
\text { Dan Potensi } \\
\text { Lahan Gambut } \\
\text { Di Kabupaten } \\
\text { Bengkalis } \\
\text { Untuk } \\
\text { Pengembangan } \\
\text { Pertanian / } \\
\text { Jurnal } \\
\text { Agaroteknologi } \\
\text { Vol } 1 \text { No } 1 \\
\text { Agustus 2010 }\end{array}$} & \multirow{10}{*}{$\begin{array}{c}\text { Besri Nasrul / } \\
2010\end{array}$} & 2006 & 1 & \multirow{10}{*}{$19 / 2=9,5$} & \multirow{10}{*}{$\begin{array}{l}2010- \\
2001=9 \\
\text { tahun }\end{array}$} \\
\hline & & & 2005 & 4 & & \\
\hline & & & 2004 & 2 & & \\
\hline & & & 2001 & 3 & & \\
\hline & & & 2000 & 3 & & \\
\hline & & & 1996 & 1 & & \\
\hline & & & 1994 & 1 & & \\
\hline & & & 1993 & 1 & & \\
\hline & & & 1991 & 2 & & \\
\hline & & & 1978 & 1 & & \\
\hline & Aplikasi & & 2004 & 3 & & \\
\hline & Analisis Shift & & 2001 & 1 & & \\
\hline & Share & & 2000 & 1 & & \\
\hline & Esteban- & & 1999 & 1 & & \\
\hline & Marquillas & & 1996 & 1 & & \\
\hline 10. & Pada Sektor & Ropingi/2006 & 1995 & 2 & $15 / 2=7,5$ & $1995=11$ \\
\hline & Pertanian Di & 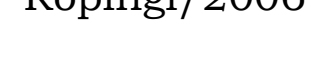 & 1993 & 2 & & tahun. \\
\hline & Kabupaten & & 1991 & 1 & & \\
\hline & Boyolali / & & 1988 & 1 & & \\
\hline & $\begin{array}{c}\text { Vol } 6 \text { No } 1 \\
\text { Februari } 2006\end{array}$ & & 1977 & 2 & & \\
\hline
\end{tabular}

Dari 10 artikel pengarang individu yang saya amati dan cermati dalam melakukan penghitungan keusangan literatur maka dapat dilihat bahwa tiap-tiap artikel memiliki tahun dengan frekuensi sitiran yang berbeda-beda. Serta terlihat terdapat beberapa artikel yang berdasarkan penghitungan median tahun sitasinya berjumlah lebih dari 14 tahun, maka dapat diperkirakan bahwa literatur tersebut telah usang.

\section{B. PARO HIDUP LITERATUR}

Istilah paro hidup (half-life) pertama digunakan oleh R. E. Borton dan R. W. Kebler tahun 1960 mereka memakai istilah "half-life" yang berarti waktu saat setengah dari seluruh literatur suatu disiplin ilmu yang digunakan secara 
terus menerus. ${ }^{4}$ Paro hidup mengacu pada adanya waktu yang diperlukan oleh suatu atom untuk meluruh menjadi setengahnya secara terus menerus hingga atom suatu unsur itu habis. Line menyatakan : "The half life of literature is bound to be shorter the more rapidly the literature growing"5. Dari pernyataan tersebut dapat disimpulkan bahwa paro hidup dari sebuah literatur adalah batas cepat tidaknya pertumbuhan dari suatu literatur. Paro hidup suatu disiplin bidang ilmu adalah rentang waktu dimana suatu literatur disiplin ilmu digunakan sebanyak 50 persen (separuh) penggunaan total dokumen itu. Untuk menghitung paro hidup suatu disiplin bidang ilmu dapat diperoleh dengan cara mengurangi median tahun terbit dokumen yang menyitir dokumen sumber dengan tahun terbit dokumen sumber.

Paro hidup dokumen dapat dihitung dengan mengurutkan semua tahun terbit dan menghitung jumlah sitiran semua dokumen pada masing-masing bidang mulai yang tertua (tahun terkecil) sampai tahun terbaru (tahun terbesar) atau sebaliknya. ${ }^{6}$ Kemudian dicari median dengan membagi jumlah kumulatif sitiran yang sudah terurut tersebut menjadi 2 (dua) masing-masing. Median tersebut terletak pada tahun berapa. Kemudian dikurangi dengan tahun tertua.

Dalam kajian bibliometrika, paro hidup merupakan tingkat keusangan literatur berdasarkan sitirannya. Kajian

${ }^{4}$ William W. Hood and concepcion S. Wilson "the literatur of bibliomatric, scienctiometrics, and informetric”, Scientiometrics. Vol 52, No 2, (2001), hlm 298

${ }^{5}$ Broadus, R.N, Early approaches to bibliometrics, Journal Of The American Society For Information Science, 38 (1987), hlm 127

${ }^{6}$ Ibid,. hlm 129 
paro hidup menitikberatkan tahun terbit seluruh jumlah sitiran pada literatur tersebut. Hal ini menunjukkan kemutakhiran kandungan informasi pada literatur ilmiah, paro hidup ini bertujuan sebagai sarana pertimbangan penulisan dalam penggunaan literatur dalam jangka waktu tertentu, dan dapat juga dijadikan indikator kekayaan atau kemiskinan informasi, serta yang paling penting adalah paro hidup dapat menunjukkan perkembangan suatu bidang ilmu pengetahuan.

Dengan begitu, berikut adalah salah satu contoh dari analisis paro hidup di bidang pertanian:

TABEL PARO HIDUP LITERATUR BIDANG PERTANIAN

\begin{tabular}{|c|c|c|c|c|c|}
\hline No & Judul & Penulis / Tahun & $\begin{array}{c}\text { Tahun } \\
\text { Muda - } \\
\text { Tua }\end{array}$ & $\begin{array}{l}\text { Selisih } \\
\text { Tahun }\end{array}$ & $\begin{array}{c}\text { Jumlah } \\
\text { sitiran }\end{array}$ \\
\hline 1. & $\begin{array}{c}\text { Pola Pertanian } \\
\text { Terpadu Ternak } \\
\text { Dan Tanaman } \\
\text { Hortikultura Di } \\
\text { Kota Pekan Baru }\end{array}$ & L. Siswati/2012 & $\begin{array}{c}2011- \\
1991\end{array}$ & 20 & 9 \\
\hline 2. & $\begin{array}{c}\text { Identifikasi Faktor- } \\
\text { Faktor Sosial- } \\
\text { Ekonomi Migrasi } \\
\text { Tenaga Kerja } \\
\text { (Kasus Ibu Rumah } \\
\text { Tangga Yang } \\
\text { Bekerja Dari Sektor } \\
\text { Pertanian Ke Sektor } \\
\text { Non Pertanian) }\end{array}$ & $\begin{array}{c}\text { Agus } \\
\text { Sumanto/2009 }\end{array}$ & $\begin{array}{c}2004- \\
1991\end{array}$ & 13 & 13 \\
\hline 3. & $\begin{array}{c}\text { Analisis Referensi } \\
\text { Teknis Usaha Tani } \\
\text { Padi Sawah } \\
\text { Aplikasi Pertanian } \\
\text { Organik (Studi } \\
\text { Kasus Didesa } \\
\text { Sumber Ngepoh, }\end{array}$ & Tien/2011 & $\begin{array}{l}2009- \\
1977\end{array}$ & 32 & 24 \\
\hline
\end{tabular}




\begin{tabular}{|c|c|c|c|c|c|}
\hline & $\begin{array}{l}\text { Kecamatan Lawang } \\
\text { Kabupaten Malang } \\
\text { 2009-2010) }\end{array}$ & & & & \\
\hline 4 & $\begin{array}{c}\text { Strategi } \\
\text { Pengembangan } \\
\text { Sektor Pertanian } \\
\text { Pasca Gempa Bumi } \\
\text { Kabupaten Bantul }\end{array}$ & $\begin{array}{c}\text { Agus Tri } \\
\text { Basuki/2008 }\end{array}$ & $\begin{array}{c}2005- \\
1988\end{array}$ & 17 & 10 \\
\hline 5 & $\begin{array}{c}\text { Karakteristik } \\
\text { Pembakaran } \\
\text { Biobriket Dari } \\
\text { Campuran Batu } \\
\text { Bara Dan Limbah } \\
\text { Padat } \\
\text { Pertanian }\end{array}$ & Wahyudi / 2007 & $\begin{array}{c}2001- \\
1975\end{array}$ & 26 & 19 \\
\hline 6 & $\begin{array}{c}\text { Potensi Lahan Di } \\
\text { Das Batang Pelepat } \\
\text { Untuk } \\
\text { Pengembangan } \\
\text { Pertanian }\end{array}$ & Sunarti/2010 & $\begin{array}{l}2000- \\
2007\end{array}$ & 7 & 8 \\
\hline 7 & $\begin{array}{c}\text { Struktur } \\
\text { Komunitas } \\
\text { Hymenopetra } \\
\text { Parasitoid Pada } \\
\text { Berbagai Lanskap } \\
\text { Pertanian Di } \\
\text { Sumatera Barat }\end{array}$ & Yaherwandi/2009 & $\begin{array}{c}2006- \\
1990\end{array}$ & 16 & 34 \\
\hline 8 & $\begin{array}{c}\text { Peran Sektor } \\
\text { Pertanian Dalam } \\
\text { Memenuhi } \\
\text { Kecukupan Pangan } \\
\text { Nasional }\end{array}$ & $\begin{array}{c}\text { Novianti } \\
\text { Muspiroh/2012 }\end{array}$ & $\begin{array}{l}2003- \\
1987\end{array}$ & 16 & 5 \\
\hline & Penyebaran Dan & & & & \\
\hline
\end{tabular}




\begin{tabular}{|c|c|c|c|c|c|}
\hline 9 & $\begin{array}{c}\text { Potensi Lahan } \\
\text { Gambut Di } \\
\text { Kabupaten } \\
\text { Bengkalis Untuk } \\
\text { Pengembangan } \\
\text { Pertanian }\end{array}$ & $\begin{array}{c}\text { Besri Nasrul / } \\
2010\end{array}$ & $\begin{array}{c}2006- \\
1978\end{array}$ & 28 & 19 \\
\hline 10 & & & & \\
& $\begin{array}{c}\text { Aplikasi Analisis } \\
\text { Shift Share } \\
\text { Esteban-Marquillas } \\
\text { Pada Sektor } \\
\text { Pertanian Di } \\
\text { Kabupaten Boyolali }\end{array}$ & Ropingi/2006 & $2004-$ & 27 & 15 \\
\hline & TOTAL & 1977 & & \\
\hline & MEDIAN & & $\mathbf{2 0 2}$ & $\mathbf{1 5 6}$ \\
\hline
\end{tabular}

Jadi dapat ditarik kesimpulan bahwa paro hidup mengenai artikel dengan bidang pertanian ini gabungan dari Sitiran 10 artikel yaitu jumlah nya 156 sedangan paro hidup yaitu separuh dari literatur atau $50 \%$ yang berarti 78 paro hidupnya. Yang berada pada artikel Sunarti di 2010 yang mempunyai referensi tahun 2000-2007. Dan juga dapat dihitung tahun artikel pertengahan yaitu 2010, yang akan dikurangi tahun sekarang 2018. Jadi, 2018-2010 yaitu 8 tahun. Dengan begitu maka dapat didapat bahwa paro hidup literatur bidang pertanian 8 tahun.

\section{ANALISIS ZIPF PADA ABSTRAK ARTIKEL BIDANG PERTANIAN}

\section{Jumlah Abstrak Artikel Bidang Pertanian}

Lima abstrak artikel bidang pertanian pada periode 2008 - 2012 sebagai sampel. 
Jumlah abstrak artikel

\begin{tabular}{|c|c|c|c|}
\hline No & Tahun & Jumlah & Persentase \\
\hline 1 & 2008 & $\begin{array}{c}1 \text { abstrak } \\
\text { artikel }\end{array}$ & $20 \%$ \\
\hline 2 & 2009 & $\begin{array}{c}1 \text { abstrak } \\
\text { artikel }\end{array}$ & $20 \%$ \\
\hline 3 & 2010 & $\begin{array}{c}2 \text { abstrak } \\
\text { artikel }\end{array}$ & $40 \%$ \\
\hline 4 & 2011 & - & $0 \%$ \\
\hline 5 & 2012 & $\begin{array}{c}1 \text { abstrak } \\
\text { artikel }\end{array}$ & $20 \%$ \\
\hline & Jumlah & $\begin{array}{c}\mathbf{5} \text { abstrak } \\
\text { artikel }\end{array}$ & $\mathbf{1 0 0} \%$ \\
\hline
\end{tabular}

Hasil dari analisis bibliomatrika dengan menggunakan hukum dalil zipf pada abstrak artikel ini bertujuan untuk dapat menghasilkan kata-kata kunci yang dapat dijadikan subjek.

\section{Analisis Pengujian Hukum Zipf Pada Abstrak Artikel}

Dalam penelitian ini metode yang digunakan adalah studi bibliometrika dengan menggunakan hukum Zipf. Hukum Zipf merupakan perhitungan kata-kata dengan frekuensi tertinggi hingga ke terendah yang akan menghasilkan kata kunci yang biasanya digunakan dalam pengindeksan subjek. Hasil kajian bibliometrika dengan menggunakan hukum Zipf ini dapat membantu dalam menentukan kata kunci ataupun tajuk subjek sebuah dokumen yang dapat digunakan dalam proses temu balik informasi. Adapun rumus hukum Zipf adalah:

$\mathrm{r} . \mathrm{f}(\mathrm{r})=\mathrm{k}$

Keterangan:

$\mathrm{R} \quad=$ Peringkat kata

$\mathrm{f}(\mathrm{r}) \quad=$ frekuensi pengulangan pada peringkat $\mathrm{r}$

$\mathrm{k} \quad=$ konstanta positif 
Analisis bibliomatrika dengan menggunakan hukum zipf ini diterapkan pada abstrak artikel milik L. Siswati, Agus Sumanto, Sunarti, Besti Nasrul, Dewi Febriana, (lihat tabel 1-5). Analisis pertama dilakukan untuk mengurutkan peringkat dari kata yang sering muncul sampai ke kata yang jarang muncul pada teks yang ada di abstrak artikel. Peringkat (r) merupakan peringkat dengan frekuensi kemunculannya dari yang tertinggi hingga ke terendah. Sedangkan, frekuensi (f) merupakan seberapa banyak frekuensi permunculan suatu kata pada teks abstrak artikel, kemudia $r x f$ merupakan nilai konstanta positif pada suatu kata. Dibawah ini adalah rangking kemunculan kata pada abstrak artikel.

Tabel 1 Peringkat Frekuensi Kemunculan kata

\begin{tabular}{|c|c|c|c|}
\hline $\begin{array}{c}\text { Peringkat } \\
(\mathrm{r})\end{array}$ & Frekuensi (f) & Rxf & Kata \\
\hline 1 & 10 & 10 & And \\
\hline 2 & 5 & 10 & Integrated \\
\hline 3 & 5 & 15 & Horticulture \\
\hline 4 & 4 & 16 & Sistem \\
\hline 5 & 4 & 20 & Of \\
\hline 6 & 4 & 24 & Cattle \\
\hline 7 & 2 & 14 & To \\
\hline 8 & 2 & 16 & Know \\
\hline 9 & 2 & 18 & Farmers \\
\hline 10 & 2 & 20 & Chicken \\
\hline 11 & 2 & 22 & Pepaya \\
\hline 12 & 2 & 24 & Fruits \\
\hline 13 & 2 & 26 & Vegetables \\
\hline 14 & 2 & 28 & Is \\
\hline 15 & 2 & 30 & Income \\
\hline $16-51$ & 1 & $\mathbf{8}$ & Berbagai kata \\
\hline Jumlah & \multicolumn{2}{|c}{} \\
\hline
\end{tabular}


Tabel 2 Peringkat Frekuensi Kemunculan kata

\begin{tabular}{|c|c|c|c|}
\hline $\begin{array}{c}\text { Peringkat } \\
(\mathrm{r})\end{array}$ & Frekuensi (f) & R x f & Kata \\
\hline 1 & 5 & 5 & Agricultural \\
\hline 2 & 4 & 8 & Of \\
\hline 3 & 4 & 12 & Non \\
\hline 4 & 3 & 12 & Factor \\
\hline 5 & 3 & 15 & Migration \\
\hline 6 & 3 & 18 & The \\
\hline 7 & 3 & 21 & Are \\
\hline 8 & 3 & 24 & Sector \\
\hline 9 & 2 & 27 & For \\
\hline 10 & 2 & 20 & Housewife \\
\hline 11 & 2 & 22 & Household \\
\hline 12 & 2 & 24 & Level \\
\hline 13 & 2 & 26 & And \\
\hline 14 & 2 & 28 & Berbagai kata \\
\hline 15 & 2 & 30 & \\
\hline $16-47$ & 1 & $\mathbf{7 4}$ & \\
\hline Jumlah & & &
\end{tabular}

Tabel 3 Peringkat Frekuensi Kemunculan Kata

\begin{tabular}{|c|c|c|c|}
\hline $\begin{array}{c}\text { Peringkat } \\
(\mathrm{r})\end{array}$ & Frekuensi (f) & Rxf & Kata \\
\hline 1 & 8 & 8 & Land \\
\hline 2 & 7 & 14 & In \\
\hline 3 & 6 & 18 & To \\
\hline 4 & 6 & 24 & And \\
\hline 5 & 4 & 20 & Is \\
\hline 6 & 4 & 24 & Suitable \\
\hline 7 & 4 & 28 & Peats \\
\hline 8 & 4 & 32 & Shallow \\
\hline 9 & 3 & 27 & Peatlands \\
\hline 10 & 3 & 30 & Distribution \\
\hline 11 & 3 & 33 & Potency \\
\hline 12 & 3 & 36 & Bengkalis \\
\hline 13 & 3 & 39 & Agriculture \\
\hline 14 & 2 & 28 & About \\
\hline 15 & 2 & 30 & It's \\
\hline 16 & 2 & 32 & Study \\
\hline 17 & 2 & 34 & Distric \\
\hline 18 & 2 & 36 & \\
\hline 19 & 2 & 38 & \\
\hline
\end{tabular}




\begin{tabular}{|c|c|c|c|}
\hline 20 & 2 & 40 & Tropical \\
\hline 21 & 2 & 42 & Crop \\
\hline $22-44$ & 1 & & Berbaagai kata \\
\hline Jumlah & \multicolumn{3}{|c}{} \\
\hline
\end{tabular}

Tabel 4 Peringkat Frekuensi Kemunculan Kata

\begin{tabular}{|c|c|c|c|}
\hline $\begin{array}{c}\text { Peringkat } \\
(\mathrm{r})\end{array}$ & Frekuensi (f) & Rxf & Kata \\
\hline 1 & 12 & 12 & The \\
\hline 2 & 10 & 20 & at \\
\hline 3 & 7 & 21 & And \\
\hline 4 & 6 & 24 & Of \\
\hline 5 & 6 & 30 & Animal \\
\hline 6 & 4 & 24 & Was \\
\hline 7 & 4 & 28 & In \\
\hline 8 & 3 & 24 & Feeding \\
\hline 9 & 3 & 27 & Crop \\
\hline 10 & 3 & 30 & Farmer \\
\hline 11 & 3 & 33 & Who \\
\hline 12 & 3 & 36 & Kept \\
\hline 13 & 3 & 39 & Night \\
\hline 14 & 2 & 28 & Residius \\
\hline 15 & 2 & 30 & Low \\
\hline 16 & 2 & 32 & System \\
\hline 17 & 2 & 34 & Out \\
\hline 18 & 2 & 36 & Animals \\
\hline 19 & 2 & 38 & Freely \\
\hline 20 & 2 & 40 & During \\
\hline 21 & 2 & 42 & Day \\
\hline $22-63$ & 1 & & Berbagai kata \\
\hline Jumlah & & $\mathbf{1 2 5}$ & \\
\hline & & \multicolumn{2}{|c}{} \\
\hline
\end{tabular}

Tabel 5 Peringkat Frekuensi Kemunculan Kata

\begin{tabular}{|c|c|c|c|}
\hline $\begin{array}{c}\text { Peringkat } \\
(\mathrm{r})\end{array}$ & Frekuensi $(\mathrm{f})$ & Rxf & Kata \\
\hline 1 & 9 & 9 & Land \\
\hline 2 & 7 & 14 & Of \\
\hline 3 & 7 & 21 & Techniques \\
\hline 4 & 6 & 24 & And \\
\hline 5 & 4 & 20 & Water \\
\hline 6 & 3 & 18 & That \\
\hline 7 & 3 & 21 & Capability \\
\hline
\end{tabular}




\begin{tabular}{|c|c|c|c|}
\hline 8 & 3 & 24 & In \\
\hline 9 & 3 & 27 & Pelepat \\
\hline 10 & 3 & 30 & Watershed \\
\hline 11 & 3 & 33 & Research \\
\hline 12 & 3 & 36 & Agricultural \\
\hline 13 & 2 & 26 & Impact \\
\hline 14 & 2 & 28 & Is \\
\hline 15 & 2 & 30 & With \\
\hline 16 & 2 & 32 & To \\
\hline 17 & 2 & 34 & Development \\
\hline 18 & 2 & 36 & Was \\
\hline 19 & 2 & 38 & By \\
\hline 20 & 2 & 40 & Unit \\
\hline 21 & 2 & 42 & Consist \\
\hline 22 & 2 & 44 & Variously \\
\hline 23 & 2 & 46 & Limiting \\
\hline 24 & 2 & 48 & Factor \\
\hline 25 & 2 & 50 & Moderate \\
\hline $26-61$ & 1 & & Berbagai kata \\
\hline Jumlah & \multicolumn{3}{|c|}{117} \\
\hline
\end{tabular}

Setelah diurutkan frekuensi kemunculan kata dari yang tertinggi hingga terendah, seperti ditabel 1-5 langkah selanjutnya adalah menentukan nilai Titik transisi Goffman, yaitu titik teoritis dimana terjadi perubahan dari frekuensi 
tinggi ke frekuensi rendah, diduga merupakan daerah yang memuat kata-kata yang menunjukkan isi dokumen. Titik transisi ini dapat dicapai bilamana kata yang mempunyai frekuensi $\boldsymbol{n}$ didekati dengan uniti atau In mendekati 1. Sehingga berpola rumus sebagai berikut:

$$
n 2+n-2 I 1=0
$$

Kemudian menggunakan rumus perhitungan titik transisi Goffman:

$$
n 1.2=12 /(-b \pm \sqrt{ }(b 2-4 a c))
$$

\section{a. Tabel 1}

$n=$ total frekuensi kata $=86$ kata

I $n=$ jumlah kata yang berbeda dengan frekuensi $\mathrm{n}$ sebanyak 51 kata

I 1 = jumlah kata yang berbeda dengan frekuensi 1 sebanyak 36 kata

$\mathrm{I} n=16-51+1$

$\mathrm{I}_{1}=36$

$\mathrm{n}^{2}+\mathrm{n}-2 \cdot \mathrm{I}_{1}=0$

$\mathrm{a}=1$

$\mathrm{b}=1$

$\mathrm{c}=-2.36=-72$

$\mathrm{n}_{1.2}=1 / 2\left(-\mathrm{b} \pm \sqrt{\mathrm{b}^{2}}-4 . \mathrm{a} . \mathrm{c}\right)$

$=1 / 2\left(-1 \pm \sqrt{ } 1^{2}-4 \cdot 1 \cdot(-72)\right.$

$=1 / 2(-1 \pm \sqrt{ } 1+288)$

$=1 / 2(-1 \pm \sqrt{2} 289)$

$=1 / 2(-1 \pm 17)$

$=1 / 2 \cdot 16$

$=8$

Berdasarkan rumus diatas, dapat diketahui nilai titik transisinya adalah "8" daerah transisi dapat meliputi daerah 8 keatas yaitu peringkat (r) $1,2,3,4,5,6,7,8$ dan daerah 8 
kebawah yaitu, peringkat (r) 8, 9,10,11,12,13,14,15 sehingga dapat diperoleh kata-kata berikut :

And, integrated, horticulture, sistem, of, cattle, to, know, chicken, pepaya, fruits, vegetable, is, income

Setelah kata-kata yang di anggap tidak penting dihapus, maka tersisa kata-kata berikut:

\section{Intergrated, horticulture, cattle, vegetable}

\section{b. Tabel 2}

$n=$ total frekuensi kata $=74$ kata

I $n=$ jumlah kata yang berbeda dengan frekuensi $\mathrm{n}$ sebanyak 47 kata

I 1= jumlah kata yang berbeda dengan frekuensi 1 sebanyak 32 kata

$$
\begin{aligned}
& \text { In }=16-47+1 \\
& \mathrm{I}_{1}=32 \\
& \mathrm{n}^{2}+\mathrm{n}-2 \cdot \mathrm{I}_{1}=0 \\
& \mathrm{a}=1 \\
& \mathrm{~b}=1 \\
& \mathrm{c}=-1 \cdot \mathrm{I}_{1}=-2 \cdot 32=-64 \\
& \mathrm{n}_{1.2}=1 / 2\left(-\mathrm{b} \pm \sqrt{ } \mathrm{b}^{2}-4 \cdot \mathrm{a} \cdot \mathrm{c}\right) \\
& =1 / 2\left(-1 \pm \sqrt{ } 1^{2}-4 \cdot 1 \cdot(-64)\right. \\
& =1 / 2(-1 \pm \sqrt{ } 1+256) \\
& =1 / 2(-1 \pm \sqrt{ } 257) \\
& =1 / 2(-1 \pm 16,03) \\
& =1 / 2 \cdot 15,05 \\
& =\mathbf{7}, \mathbf{5 1 5}=\mathbf{8}
\end{aligned}
$$

Berdasarkan rumus diatas, dapat diketahui nilai titik transisinya adalah "8" daerah transisi dapat meliputi daerah 8 keatas yaitu peringkat (r) 1,2,3,4,5,6,7, 8 dan daerah 8 
kebawah yaitu, peringkat (r) 8, 9,10,11,12,13,14,15 sehingga dapat diperoleh kata-kata berikut :

Agricultural, of, non, factor, migration, to, the, are, sector, for, housewife, workers, household, level, and.

Setelah kata-kata yang di anggap tidak penting dihapus, maka tersisa kata-kata berikut:

\section{Agricultural, factor, migration, sector.}

\section{c. Tabel 3}

$n=$ total frekuensi kata $=81$ kata

I $n=$ jumlah kata yang berbeda dengan frekuensi $\mathrm{n}$ sebanyak 44 kata

I 1= jumlah kata yang berbeda dengan frekuensi 1 sebanyak 23 kata

$$
\begin{aligned}
& \mathrm{In}=22-44+1 \\
& \mathrm{I}_{1}=23 \\
& \mathrm{n}^{2}+\mathrm{n}-2 \cdot \mathrm{I}_{1}=0 \\
& \mathrm{a}=1 \\
& \mathrm{~b}=1 \\
& \mathrm{c}=-2 \cdot 23=-46 \\
& \mathrm{n}_{1.2}=1 / 2\left(-\mathrm{b} \pm \sqrt{ } \mathrm{b}^{2}-4 . \mathrm{a} . \mathrm{c}\right) \\
& =1 / 2\left(-1 \pm \sqrt{ } 1^{2}-4 \cdot 1 \cdot(-46)\right. \\
& =1 / 2(-1 \pm \sqrt{ } 1+184) \\
& =1 / 2(-1 \pm \sqrt{ } 185) \\
& =1 / 2(-1 \pm 13,60) \\
& =1 / 2 \cdot 12,60 \\
& =\mathbf{6 , 3}=\mathbf{6}
\end{aligned}
$$

Berdasarkan rumus diatas, dapat diketahui nilai titik transisinya adalah "6" daerah transisi dapat meliputi daerah 6 keatas yaitu peringkat (r) 1,2,3,4,5, 6 dan daerah 6 
kebawah yaitu, peringkat (r) 6,7,8,9,10,11 sehingga dapat diperoleh kata-kata berikut :

Land, in, to, the, and, is,suitable, peats, shallow, peatlands, distribution.

Setelah kata-kata yang di anggap tidak penting dihapus, maka tersisa kata-kata berikut:

\section{Land, peatlands, distribution.}

\section{d. Tabel 4}

$n=$ total frekuensi kata $=125 \mathrm{kata}$

I $n=$ jumlah kata yang berbeda dengan frekuensi $\mathrm{n}$ sebanyak 63 kata

I 1= jumlah kata yang berbeda dengan frekuensi 1 sebanyak 42 kata

$$
\begin{aligned}
& \mathrm{I} n=22-63+1 \\
& \mathrm{I}_{1}=42 \\
& \mathrm{n}^{2}+\mathrm{n}-2 \cdot \mathrm{I}_{1}=0 \\
& \mathrm{a}=1 \\
& \mathrm{~b}=1 \\
& \mathrm{c}=-2.42=-84 \\
& \mathrm{n}_{1.2}=1 / 2\left(-\mathrm{b} \pm \sqrt{ } \mathrm{b}^{2}-4 \cdot \mathrm{a} . \mathrm{c}\right) \\
& =1 / 2\left(-1 \pm \sqrt{ } 1^{2}-4.1 \cdot(-84)\right. \\
& =1 / 2(-1 \pm \sqrt{ } 1+336) \\
& =1 / 2(-1 \pm \sqrt{ } 337) \\
& =1 / 2(-1 \pm 18,35) \\
& =1 / 2 \cdot 17,35 \\
& =\mathbf{8 , 6 7}=\mathbf{9}
\end{aligned}
$$

Berdasarkan rumus diatas, dapat diketahui nilai titik transisinya adalah "9" daerah transisi dapat meliputi daerah 9 keatas yaitu peringkat (r) 1,2,3,4,5,6,7, 8, 9 dan daerah 9 
kebawah yaitu, peringkat (r) 9,10,11,12,13,14,15,16 sehingga dapat diperoleh kata-kata berikut :

The, at, and, of, animal, was, in, feeding, crop, who, kept, night, residius, low, system.

Setelah kata-kata yang ti anggap tidak penting dihapus, maka tersisa kata-kata berikut:

\section{Animal, crop, residius, system}

\section{e. Tabel 5}

$n=$ total frekuensi kata $=117 \mathrm{kata}$

I $n=$ jumlah kata yang berbeda dengan frekuensi $\mathrm{n}$ sebanyak 61 kata

I 1= jumlah kata yang berbeda dengan frekuensi 1 sebanyak 36 kata

$$
\begin{aligned}
& \text { I } n=26-61+1 \\
& \mathrm{I}_{1}=36 \\
& \mathrm{n}^{2}+\mathrm{n}-2 \cdot \mathrm{I}_{1}=0 \\
& \mathrm{a}=1 \\
& \mathrm{~b}=1 \\
& c=-2.36=-72 \\
& \mathrm{n}_{1.2}=1 / 2\left(-\mathrm{b} \pm \sqrt{ } \mathrm{b}^{2}-4 . \mathrm{a} . \mathrm{c}\right) \\
& =1 / 2\left(-1 \pm \sqrt{ } 1^{2}-4 \cdot 1 \cdot(-72)\right. \\
& =1 / 2(-1 \pm \sqrt{ } 1+288) \\
& =1 / 2(-1 \pm \sqrt{ } 289) \\
& =1 / 2(-1 \pm 17) \\
& =1 / 2 \cdot 16 \\
& =8
\end{aligned}
$$

Berdasarkan rumus diatas, dapat diketahui nilai titik transisinya adalah "8" daerah transisi dapat meliputi daerah 8 keatas yaitu peringkat (r) $1,2,3,4,5,6,7,8$ dan daerah 8 
kebawah yaitu, peringkat (r) 8, 9,10,11,12,13,14,15 sehingga dapat diperoleh kata-kata berikut :

Land, of, techniques, and, water, that, capability, in, pelepat, watershed, research, agricultural, impact, is, with.

Setelah kata-kata yang ti anggap tidak penting dihapus, maka tersisa kata-kata berikut:

Land, techniques, capability, research, agriciltural.

Selanjutnya berdasarkan kata kunci yang telah ditemukan diatas dapat dianalisis atau dikelompokkan kedalam subjek penelitian bidang pertanian, yang dapat digambarkan melalui tabel berikut:

Subjek Penelitian Bidang Pertanian

\begin{tabular}{|c|c|c|}
\hline No & Sub Divisi & Kode \\
\hline 1 & $\begin{array}{c}\text { Teknik tertentu: alat, perlengkapan, } \\
\text { materi }\end{array}$ & T.01 \\
\hline 2 & Kerusakan, penyakit, hama tanaman & T.02 \\
\hline 3 & $\begin{array}{c}\text { Tanaman ladang dan pertanian, } \\
\text { perkebunan }\end{array}$ & T.03 \\
\hline 4 & $\begin{array}{c}\text { Kebun buah-buahan, buah-buahan, } \\
\text { kehutanan }\end{array}$ & $\begin{array}{l}\text { T.04 } \\
\text { T.05 }\end{array}$ \\
\hline 5 & Tanaman kebun, sayur-sayuran & T.06 \\
\hline 6 & Perternakan & T.07 \\
\hline 7 & $\begin{array}{c}\text { Pengolahan hasil ternak dan produk } \\
\text { budidaya serangga }\end{array}$ & T.08 \\
\hline 8 & $\begin{array}{c}\text { Berburu, penangkapan ikan, } \\
\text { konservasi, teknologi }\end{array}$ & T.09 \\
\hline
\end{tabular}

Hasil Analisis Pengujian Hukum Zipf Pada 5 Abstrak Artikel Bidang Pertanian

\begin{tabular}{|c|c|c|c|c|c|}
\hline No & Nama & Tahun & $\begin{array}{c}\text { Titik } \\
\text { transisi }\end{array}$ & Kata kunci & Subjek \\
\hline 1 & $\begin{array}{c}\text { Dewi } \\
\text { Febrina }\end{array}$ & 2008 & 8 & Animal, crop, residius, & T.09 \\
\hline
\end{tabular}




\begin{tabular}{|c|c|c|c|c|c|}
\hline 2 & $\begin{array}{c}\text { Agus } \\
\text { Sumanto }\end{array}$ & 2009 & 8 & $\begin{array}{c}\text { Agricultural, factor, } \\
\text { migration, sector. }\end{array}$ & T.03 \\
\hline 3 & Sunarti & 2010 & 8 & $\begin{array}{c}\text { Land, techniques, } \\
\text { capability, research, } \\
\text { agriciltural. }\end{array}$ & T.01 \\
\hline 4 & $\begin{array}{c}\text { Besri } \\
\text { Nasrul }\end{array}$ & 2010 & 6 & $\begin{array}{c}\text { Land, peatlands, } \\
\text { distribution. }\end{array}$ & T.03 \\
\hline 5 & L. Siswati & 2012 & 9 & $\begin{array}{c}\text { Intergrated, horticulture, } \\
\text { cattle, vegetable }\end{array}$ & T.08 \\
\hline
\end{tabular}

\section{Hasil Pengelompokkan Subjek}

Berdasarkan analisis pengelompokkan subjek yang telah dilakukan pada 5 abstrak artikel, berikut ini adalah persentase hasil keseluruhan dari pengelompokkan dan persentase dari subjek bidang pertanian yaitu:

\section{Persentase Penggolongan Subjek}

\begin{tabular}{|c|c|c|c|c|c|c|c|c|}
\hline \multirow[t]{2}{*}{ No } & \multirow[t]{2}{*}{ Subjek } & \multicolumn{5}{|c|}{ Tahun } & \multirow[t]{2}{*}{ Jumlah } & \multirow[t]{2}{*}{ Presentase } \\
\hline & & 2008 & 2009 & 2010 & 2011 & 2012 & & \\
\hline 1 & T.01 & 0 & 0 & 1 & 0 & 0 & 1 & $20 \%$ \\
\hline 2 & T.02 & 0 & 0 & 0 & 0 & 0 & 0 & $0 \%$ \\
\hline 3 & T.03 & 0 & 1 & 1 & 0 & 0 & 2 & $40 \%$ \\
\hline 4 & T.04 & 0 & 0 & 0 & 0 & 0 & 0 & $0 \%$ \\
\hline 5 & T.05 & 0 & 0 & 0 & 0 & 0 & 0 & $0 \%$ \\
\hline 6 & T.06 & 0 & 0 & 0 & 0 & 0 & 0 & $0 \%$ \\
\hline 7 & T.07 & 0 & 0 & 0 & 0 & 0 & 0 & $0 \%$ \\
\hline 8 & T.08 & 0 & 0 & 0 & 0 & 1 & 1 & $20 \%$ \\
\hline 9 & T.09 & 1 & 0 & 0 & 0 & 0 & 1 & $20 \%$ \\
\hline \multicolumn{2}{|c|}{ Jumlah } & 1 & 1 & 2 & 0 & 1 & 5 & $100 \%$ \\
\hline
\end{tabular}

\section{Perkembangan Subjek Penelitian}

Perkembangan subjek penelitian artikel di bidang pertanian berdasarkan pengelompokan subjek sub devisi di Dewey Decimal Classification 


\section{Grafik Perkembangan Subjek Penelitian}

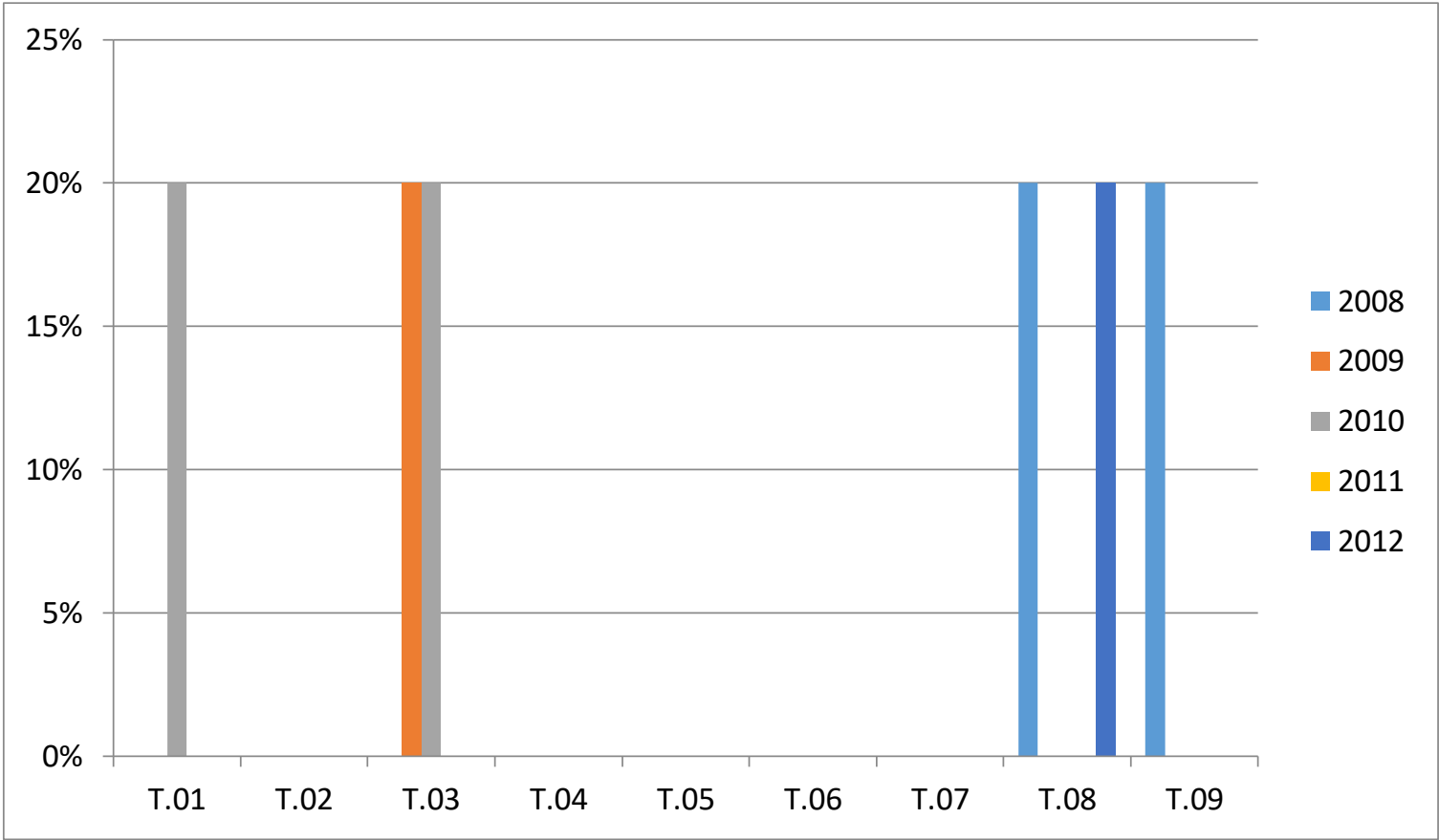

Berdasarkan grafik tersebut dapat ditarik kesimpulan bahwa selama periode tahun 2008-2012 dalam 5 artikel terlihat bahwa subjek yang paling dominan dilakukan penelitian adalah subjek tentang Tanaman ladang, pertanian, dan perkebunan. Dengan presentase total 40\%, dengan begitu maka cenderung minat penelitian dibidang ini tertuju ke subjek tanaman ladang, pertanian, dan perkebunan. Serta terdapat juga beberapa penelitian yang dilakukan pada subjek Teknik tertentu: alat, perlengkapan, materi, Pengolahan hasil ternak dan produk budidaya serangga, serta Berburu, penangkapan ikan, konservasi, teknologi. Pada subjek-subjek tersebut terlihat $20 \%$ penelitiannya. Sedangkan untuk subjek yang lainnya masih belum ada dilakukannya penelitian penulisan karya ilmiah berupa artikel. 


\section{KESIMPULAN}

Berdasarkan hasil dari analisis keusangan, paro hidup literatur, dan frekuensi kata melalui dalil zipf maka dapat diambil kesimpulan bahwa keusangan literatur pada bidang pertanian setelah di amati dan dicermati terlihat terdapat beberapa artikel yang berdasarkan penghitungan median tahun sitasinya berjumlah lebih dari 14 tahun, maka dapat diperkirakan bahwa literatur tersebut telah usang.

Sedangkan untuk paro hidup dari 10 artikel bidang pertanian, paro hidupnya terletak di pengarang Sunarti tahun 2010 yang mempunyai referensi tahun 2000-2007. Dan untuk hitungan paro hidupnya dihitung tahun artikel pertengahan yaitu 2010, yang akan dikurangi tahun sekarang 2018. Jadi, 2018-2010 yaitu 8 tahun. Dengan begitu maka dapat didapat bahwa paro hidup literatur bidang pertanian 8 tahun.

Serta untuk analisa zipf didapatkan kesimpulan bahwa selama periode tahun 2008-2012 dalam 5 artikel terlihat bahwa subjek yang paling dominan dilakukan penelitian adalah subjek tentang Tanaman ladang, pertanian, dan perkebunan. Dengan presentase total 40\%, dengan begitu maka cenderung minat penelitian dibidang ini tertuju ke subjek tanaman ladang, pertanian, dan perkebunan. Serta terdapat juga beberapa penelitian yang dilakukan pada subjek Teknik tertentu: alat, perlengkapan, materi, Pengolahan hasil ternak dan produk budidaya serangga, serta Berburu, penangkapan ikan, konservasi, teknologi. Pada subjek-subjek tersebut terlihat 20\% penelitiannya. Sedangkan untuk subjek yang lainnya masih belum ada dilakukannya penelitian penulisan karya ilmiah berupa artikel. 


\section{DAFTAR PUSTAKA}

Broadus, R.N, Early approaches to bibliometrics. 1987. Journal Of The American Society For Information Science.

Line and Sandison. 1988. Pengantar ilmu informasi: buku pedoman. Jakarta: pusat antar universitas ilmu komputer universitas indonesia.

Sitti husaebag pattah. 2013. Pemanfaatan kajian bibliometrika sebagai metode evaluasi dan kajian dalam perpustaakaan dan informasi. Khazanah al-hiqmah Vol 1. No 1

Sulistyo basuku. 2004. Pengantar dokumentasi. Bandung: rekayasa sains.

William W. Hood and concepcion S. Wilson. 2001. "the literatur of bibliomatric, scienctiometrics, and informetric". Scientiometrics. Vol 52, No 2. 